\title{
VIAGEM AO FUNDO DO RIO
}

Resumo

$>$

Esse texto nasce mais de um sentimento, que veio durante e após o falecimento de João das Neves, do que de uma análise acadêmica de seus trabalhos. Sentimento esse que aciona uma memória emotiva da experiência de ter trabalhado com ele e de ter sido uma das pessoas chamadas para compor o grupo que permaneceu em sua casa, em Lagoa Santa (MG/BR), durante os dias de sua despedida. Essa memória, levou-me a buscar alguns contextos acreanos de leitura e experiência, alguns dos quais o autor se valeu para a escritura de textos, como Yuraiá - o rio de nosso corpo (1992).

Palavras-chave:

Teatro. Memória. Paixão. Morte. Experiência. 


\title{
VIAGEM AO FUNDO DO RIO
}

\author{
Maria do Perpétuo Socorro Calixto Marques'
}

\footnotetext{
${ }^{1}$ Professora no Curso de Artes Cênicas da Universidade Federal de Uberlândia. Pesquisa o trabalho de João das Neves desde que fez parte do Grupo Poronga, em Rio Branco-Acre (1988-1992). Autora dos livros $A$ cidade encena a floresta (2005), no qual há um capítulo sobre Tributo a Chico Mendes (1988), documentário de João das Neves, e João das Neves: Opinião na Amazônia (2016). Bolsista Capes (Pós-doc) no período de agosto de 2015 a janeiro de 2016. E-mail: mcalixtomarques@uol.com.br
}

Comecei, muito jovem, a trabalhar com o diretor João das Neves, assim como outros que estão presentes nesta coletânea. Porém, em um lugar muito longe dos territórios onde o teatro ganha maior visibilidade, como a cidade natal de João das Neves, Rio de Janeiro, São Paulo ou até Belo Horizonte, onde ele ficou até o fim de sua jornada. É para esses polos que vão os espetáculos que dão certo nos grupos de teatro, pois neles, certamente, o espaço da apresentação estará lotado, especialmente em São Paulo. Nada de novidade até aí. Embora saibamos que, de 
sua mega população, um trisco de percentual lota um pequeno teatro.

Em Rio Branco, João das Neves era o 'João', diretor convidado que chegou à cidade para ministrar oficinas de teatro e logo após voltaria ao Rio de Janeiro. Não voltou. Ficou, apaixonou-se pela cidade, pelo seu povo e lá teve sua primeira filha - Maria João - e "adotou" muitos outros filhos que começaram a fazer teatro com ele.

Rio Branco não é uma cidade fácil; além de distante, e exatamente pela distância geográfica, alguns artistas e, indiretamente, pessoas comuns, se fazem resistentes ao estrangeiro. Nas décadas de 1970 e 1980, essa resistência dava-se, ou porque sentiam medo e insegurança diante do aumento desenfreado da violência gerada pela ocupação das terras devolutas nas periferias dos centros urbanos, resultado da expulsão de milhares de famílias dos seringais acreanos desde 1960, ou porque essa migração diminuía os espaços de vivência na cidade. Ou tudo junto. ${ }^{2}$

De resto, a população, em sua maioria, não sentia negativamente os impactos desse processo migratório, pois ela própria, agente dele, com suas famílias, ficava feliz em ver seus parentes e queridos conhecidos ou amigos migrarem para a cidade. Ali, pelo menos, podiam estudar e entrar em um fila de atendimento de saúde. Inclusive casar no civil, no papel 'passado', novidade, inclusive para meus pais.

Se Rio Branco, capital, não era fácil para quem nela morava ou fixava residência, viver nos seringais, hoje, quase inexistentes, era bem pior. Longe da capital, eram lugares ermos aonde se chegava apenas de barco. As viagens demoravam dias, pois o transporte não se servia de estradas e os rios sempre desembocavam nos dois afluentes do Amazonas: o Purus e o Juruá. Logo era comum pessoas que moravam no vale do Purus não conhecerem as que moravam no vale do Juruá e seus moradores serem identificados pelo nome do rio ao qual estavam perto. Logo, nascer no Juruá, no Moa, no Purus, no rio Breu etc., eram nossas bússolas geográficas ${ }^{3}$. E João das Neves mergulhou nessa referência, ao escolher o rio Acre para que fossem jogadas parte de suas cinzas. Foi um filho do rio Jordão, ou Yuraiá, para os índios Caxinauás, quando escreveu, ao longo

\footnotetext{
${ }^{2}$ Para mais informações, o leitor pode consultar: CALIXTO, Maria do Perpétuo Socorro. A Cidade encena a Floresta. Rio Branco: EDUFAC, 2005.

${ }^{3}$ Expressões utilizadas por Leandro Tocantins em O rio comanda a vida. In: SILVA, Laélia Rodrigues da Silva. Procura-se uma Pátria: a literatura no Acre (1900-1990). Porto Alegre: PUC-RS, 1996.
} 
de dois anos, sua peça Yuraiá - o rio do nosso corpo (1992), texto que analisei ainda em minha dissertação de mestrado e que volta, com mais propriedade, creio eu, em João das Neves: Opinião na Amazônia (2016). Mesmo que ele não tenha gostado da capa do livro: uma foto de quando ele ganhou o prêmio Molière, por seu belo espetáculo O Último Carro (1976), João gostou do livro. Não me disse, mas disse a Titane e a Ylka Zanotto. ${ }^{4} \mathrm{Se}$ não tivesse gostado também me diria. Ele era assim, franco, "na lata". Mas a foto da contra capa amenizou a situação, pois as duas desembocam no mesmo rio: a trajetória desse homem simples, espetacular e exigente com atores ou quaisquer pessoas que se envolvessem com a arte teatral, pois que não fez teatro como colônia de férias, mas como profissão de fé e de fogo, quase sempre sem dinheiro. Como os seringueiros que defendem suas terras nas florestas estão em seus lugares de escolhas, não pelo exotismo de morar na floresta e, no caso de João, homem de teatro, mas pela necessidade e pelo pertencimento à sua terra, aos seus rios e a sua arte. Tudo respectivamente, leitor.

\section{O rio comanda a vida}

Os acreanos são filhos do rio, nunca da terra ou da cidade. Daí expressões como: nasci no Juruá, casei no Purus, vim do AltoAcre, morei no Moa, sou filho do Abunã.

(Leandro Tocantins. $O$ rio comanda a vida.)

Voltemos a um dos filhos dos rios: antes isolados na floresta, seringueiros e índios passaram a ser afrontados por pecuaristas, desde os anos de 1960 (assim como João das Neves foi afrontado ainda no grupo Os Duendes, na cidade de Campos/Rio de Janeiro, quando dirigia o teatro daquela cidade). Como resultado, ou foram parar nas cidades ou criaram resistência para enfrentar o desenvolvimento e a expansão projetados pelo governo federal para povoar a Amazônia. O Acre era a última fronteira a ser ocupada. E para ocupar, era necessário desocupar. Iniciada, a desocupação gerou resistência por parte da classe artística, empolgando e instigando artistas de inúmeras áreas. O teatro, por suas características efêmeras, liderava ações emergenciais e era utilizado pelos

\footnotetext{
${ }^{4}$ A primeira, esposa de João das Neves. A segunda, crítica de teatro e autora do prefácio do mesmo livro.
} 
padres vinculados à linha da Teologia da Libertação. Nascia, em nossa margem, um teatro forte, de militância, a luz de um teatro agit-prop, sobre o qual me debruço em $A$ cidade encena a floresta (2005); na outra margem, longe de rio Branco, João das Neves entrou para o CPC - Centro popular de Cultura - da Une e posteriormente, fundou, com vários artistas de igual importância, o Grupo Opinião (1964). Duas margens de um mesmo rio - o teatro de militância - desaguavam, se faziam frondosos diante das situações adversas já conhecidas pelo menos pelos pesquisadores de teatro - e um dia se encontraram na mesma foz: o encontro de João das Neves com jovens acreanos. Afinal, a arte, como as águas, é sempre resistente e caudalosa.

Pronto, estava montado o cenário para um teatro documentário e de agitação e propaganda, também utilizado, naqueles tempos, na periferia de São Paulo e em outros lugares mais distantes como a extinta União Soviética. Sobre esse assunto e sua relação direta com a arte e vida de João das Neves, falo com mais verticalidade no livro A cidade encena a floresta (2005). No entanto, o livro não é dedicado somente a ele, evidentemente. Aquele teatro era feito e qua- se sempre assistido por artistas de outras áreas e por ex-seringueiros ou, ainda, por seringueiros, moradores da mata, como costumávamos nomear os que viviam na floresta. Moradores da mata que não tinham acesso à leitura e ao ensino formal. Logo, dadas às devidas proporções, estava configurado um público semelhante quando da formação da península ibérica: público simples, ouvintes das sagradas escrituras e leitores da floresta. A grande maioria de espectadores não sabia ler e o que conheciam chegava através das narrativas bíblicas, como constatado quando entrei no processo de letramento e leitura apresentado por Darnton (1986), em especial no capítulo sobre quais materiais impressos os camponeses liam, e por Chartier (1990) que destaca alguns gêneros lidos ou 'ouvidos' em seu livro A história cultural: entre práticas e representações: versões abreviadas e histórias da bíblia, catecismos, recolhas de cânticos (a música era também uma manifestação comum), livros de orações, breviários paroquiais, obras de devoção e piedade; coleção de livros de cordel. No nosso caso, a literatura de cordel construiu um espaço de leitura até hoje lembrado por pessoas que aprenderam a ler nos seringais. Como esse texto é feito de 
quadros - quadros de minha memória -, faço aqui um aparte para mostrar a foto de meu clã familiar publicado em alguns trabalhos acadêmicos, para mostrar parte do contexto sócio cultural das famílias que moravam em seringais na Amazônia, não para falar de mim, mas para apontar um raro registro de uma escola, isolada na floresta do vale do Juruá, e na qual os processos de leitura se davam via literatura de cordel. E para registrar o comentário de minha mãe, quando leu a peça Yuraiá - o rio do nosso corpo: "Esse homem esqueceu de colocar o que havia de melhor na personagem Pedro Biló....ele enfeitiçava os índios, seringueiros e todos ficavam assim óh!" (MARQUES, 1989), mostrava com seu corpo envelhecido como esses grupos eram rendidos por um dos grandes responsáveis pelas correrias ${ }^{5}$ nos seringais. Minha mãe queria o realismo fantástico na cena, apresentada no texto Yuraiá, na passagem em que os índios usam a ayahuasca. Assim, como minha mãe era fascinada pelo realismo fantástico, cuja recepção poderia levá-los ao quadro do melodrama, outros leitores/ ouvintes também eram. Falei para o João das Neves, ainda por volta de 1993. Ele me disse, sorrindo: "Diga para sua mãe que fica para a próxima...". Mamãe, volta aqui, nesse artigo, registrada em uma foto de uma escola multisseriada, no seringal Boa Esperança, na cidade de Tarauacá, onde nasceu e por onde João das Neves passou para subir o rio e chegar na aldeia Kaxinauá.

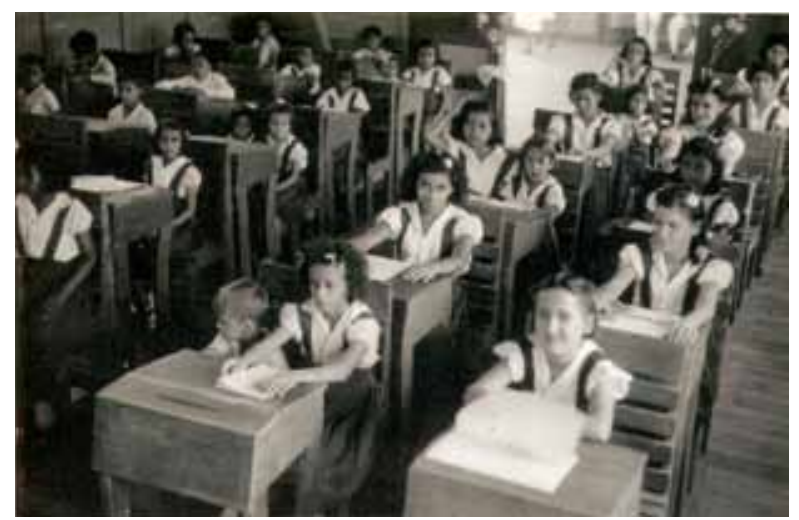

Fig. 1 - Local da foto: Seringal Boa Esperança - Escola Cel. Júlio Roque (Rio Tarauacá) - Ano 1950. Alunos identificados: Primeira fila à direita: Lindalva Calixto Marques (13anos), Anizia Calixto (15anos), Maria José Santos (12anos), Raimunda Calixto (17anos). (Minhas tias, pelo lado materno); Segunda fila (da direita para esquerda): Francisca Mourão, Raimundo Nonato Mourão Marques (tios, pelo lado paterno), Aglair, Francisca Mourão da Costa (tia Franci, pelo lado paterno), "Dica", Nazaré Viana. ${ }^{6}$ Arquivo: Pessoal (Foto que faz parte do acervo da família Mourão Marques)

Retomando. Posso dizer que esse era o perfil do leitor para o qual o melodrama se dirigia, gênero popular e corrente nos séculos XVIII e XIX. E, mesmo sem

\footnotetext{
${ }^{5}$ Correria: Termo utilizado na região significando matança organizada dos grupos indígenas pelos seringalistas. In: SILVA, Laélia Rodrigues da Silva. Procura-se uma Pátria: a literatura no Acre (1900-1990). Porto Alegre: PUC-RS, 1996.

${ }^{6}$ Foto publicada na dissertação de Mestrado de Valéria Barbosa Ferreira Silveira. Universo oral do seringueiro acreano no início do século XX: Discurso e Memória. 2011. Dissertação (Mestrado em Letras- Linguagem e Identidade) - Universidade Federal do Acre. Orientadora: Maria do Perpétuo Socorro Calixto Marques.
} 
trabalhar com o efeito patético, uma vez que o teatro de João das Neves prevê o efeito de distanciamento (Brecht, 2005), a configuração do público para o qual suas peças foram apresentadas assemelhava-se ao público do melodrama, quando este surgiu em meados do século XVIII, ainda na França.

Não sei se alguém já fez essa relação: estudar o melodrama para associar o perfil do público ao do teatro político realizado no Acre, ao qual as peças eram, inicialmente, dirigidas. Essa associação veio depois de anos de pesquisa, quando somei o contexto histórico que subsidiava o surgimento dos contos de fada e o que abrangia a história da leitura da França oitocentista. Para essa relação, foram feitos alguns movimentos de leitura, desde os apresentados por Darnton, especialmente seu célebre livro $O$ grande massacre dos gatos (1986), bem como temas sobre o conteúdo, a forma e o material do livro de Mikhail Bakhtin, Estética da Criação Verbal (1997) e A história cultural, de Chartier (1990) e, claro, o estudo de Jean-Marie Thomasseau, $O$ melodrama clássico (1800-1823).

Esses caminhos sustentam minha hipótese de que o teatro de João das Neves nascia de um processo de criação que ele, sensivelmente, observava em seu entorno e não era somente vinculado a mecanismos de atuação e composição vislumbrados por Bertolt Brecht (18981956), ou autores vinculados a uma teoria marxista, as quais sustentavam sua produção nesse universo.

O carimbo do teatro político de resistência, realizado nas décadas posteriores ao Ato Institucional $\mathrm{n}^{\mathrm{o}} 5$, após o golpe de 1964 - quando ele, João, também estava no prédio da UNE, quando este foi invadido pelos militares -, foi dado pela crítica, por ele mesmo, mas que em algumas leituras que fiz de suas peças, a exemplo de $O$ Quintal, coloca-se em debate o lado maniqueísta das peças documentários. Em sua peça O Quintal, João das Neves registrou vários pontos de vista, dentre eles sua posição representada pelas personagens Clara e Luiz e pelo fim trágico dos operários. Posição que não é maniqueísta, tão própria de momentos assim. Ao contrário, ao longo da peça, inserida no livro quem é o povo brasileiro, João questiona o movimento e seu próprio teatro. Ao final, faz a opção pelo povo. Coloco aqui um recorte de análise feita sobre $O$ Quintal, no intuito de registro sobre o homem João das Neves, para além de seus documentários, alguns encomendados, que tantas vezes analisa- 
do o fizeram ser contextualizado como diretor de militância política:

Aqui, nós podemos dizer que essa interrupção que imobiliza os acontecimentos daquele dia $1^{\circ}$, faz com que o próprio autor tome uma posição quanto ao seu papel de dramaturgo. Não que não tenha tomado antes, mas é aqui em $O$ Quintal que vislumbramos essa tomada de posição quanto às ações que nortearão o seu fazer teatral. É como se ali, naquele quintal de meninos sinceros, o acontecimento, suspenso na peça, amadurecesse a ideia do homem político de fazer de seu teatro um encontro, na acepção do termo, com o povo. Se na peça ele conta como foi e reconta, desdiz o dito e não termina, interrompe a sequência e abre a cena para perguntas, para reflexões, para ele, a resposta será dada no percurso de um teatro de militância onde o seu partido será o povo. E faz teatro nos quintais do Brasil. Vai até o povo para contar suas histórias. Faz de índios no Acre, gente do Vale do Jequitinhonha, negros das Minas Gerais, mulheres, trabalhadores que viajam nos trens urbanos, narradores e atores. (MARQUES, 2016, p. 41-42)

Não estou dizendo que o teatro de João das Neves não tenha sido feito dentro de um contexto que o levou ao teatro documentário. Quero deixar registrado é que esse teatro, mesmo escrito de forma rápida e rudimentar, foi realizado com o mesmo empenho quando ele pensou na encenação e na contribuição do ator na interpretação dos papéis. João das Neves dirigia atores e deles não tirava somente a personagem - sim, ele trabalhava com a ideia de personagem, hoje discutida pela ideia da presença na performance - mas também o mais difícil: a alma política do ator.

Como contraponto, apresen- to outro momento do diretor. Vi mais uma vez João conseguir este trabalho com o ator muitos anos depois, na montagem de Primeiras Estórias (2005-2006), texto espetacular que resultou da adaptação dos contos de Guimarães Rosa, mas que chegou aos atores somente um mês antes da estreia, quando toda a turma, alunos formandos da Unicamp, conseguira construir seus personagens sem ter acessado as falas que dariam durante o espetáculo. Em conversa com uma amiga, atriz de Primeiras Estórias, fiquei sabendo que a personagem que ela criara naquele ano de trabalho, era constantemente comprada para outros espetáculos. Dona Fia se chamava. Saiu do campo de criação de João das Neves e da atriz Simone Evaristo e ganhou o mundo como uma personagem universal. $\mathrm{Na}$ oportunidade de acompanhar diariamente os ensaios de Primeiras Estórias na Unicamp, no ano de $2005 \mathrm{eu}$, intuitivamente, fiz um diário. Nele há anotações repetidas de ações físicas, de análise de texto, de seminários abertos com pesquisadores da obra de Guimarães, ensaios com o músico Rufo Herreira, que também observava o andamento da criação para compor as músicas, cujos sons saiam de instrumentos de trabalho de campo. 
Bonito de se ver o final. Mas confuso, abstrato, quando do processo de criação do texto espetacular, pois ele partiu de uma célula que, gradativamente, ia se compondo com os exercícios corpóreo-vocais realizados pelos atores. Tudo muito lento. Bem, destaco esse exemplo, porque foi um dos poucos que eu acompanhei do início ao fim, como observadora, após os trabalhos realizados em Rio Branco com a famosa 'trilogia acreana': Caderno de Acontecimentos (1987), Tributo a Chico Mendes (1988) e Yuraiá: o rio do nosso corpo (1992). ${ }^{7}$

Em outra conversa sobre esse assunto de composição atoral, uma pesquisadora do trabalho de Stanislavski me disse: "Mas isso é Stanislavski!". Sim, João das Neves deixou claro que lia muito sobre os trabalhos de diretores, desde os mais clássicos até o de seus conterrâneos e contemporâneos. E de cada um, se valeu do que lhe interessava. Boal foi um deles e, novamente, digo que João não trabalhava com o teatro do oprimido; podia sim emprestar um jogo aqui e ali, mas seu olhar estava para o universo da obra e para o trabalho de ator. Infelizmente, sua linha mar- xista e de alguns admiradores o enclausurou no método Brecht que, por sua vez, nunca disse que tinha um método. $\mathrm{O}$ fato é que na lista de diretores como Stanislavski, Brecht, Boal, acrescento o nome de João das Neves com o cuidado de não o vincular a um diretor a ser seguido, pois corremos o risco de apagar sua poética, sua autoria e sua vontade de ver o outro em processo de crescimento. E creio, quando leio trabalhos acadêmicos, que esse apagamento se concretizou - o meu foi um deles. Vejo que muitos trabalhos sustentam seus procedimentos sempre em exemplos já utilizados, mais conhecidos e, especialmente, estrangeiros. Pressão da academia e do vício, creio eu.

Alguns leitores gritam quando unimos Stanislavski e Brecht. Agora, suponho, alguns deverão bradar mais diante da relação que fiz entre esse público com o melodrama . João das Neves não estava 'nem aî́ para os reclamos e ditames da academia. Leu $A$ cidade encena a floresta e nunca, mas nunca mesmo, demonstrou, pelo menos para mim, que concordava ou não com o caminho que eu escolhera. Deixou-me seguir e me descobrir como

7 As peças que possuo em meu acervo são da época em que integrava o Grupo Poronga. Digitadas, enviei ao João das Neves e a sua esposa Titane para integrar o acervo da exposição no Itaú Cultural e ao acervo da UFMG. Utilizei-as para fins acadêmico e com autorização do autor, quando em vida. 
pesquisadora e professora de uma instituição pública, assim como deixava seu ator se descobrir e seguir seu caminho na arte e na vida. E vimos isso em seus últimos dias, em sua casa, em Lagoa Santa, quando tive tempo de ouvi-lo: "Titane, arrume colchões para meus filhos e minhas filhas...", frase ecoada quando cheguei e o encontrei ainda em sã consciência. A casa, lotada de pessoas de várias gerações, de vários lugares. Choro, riso, cachaça, comida, tambores e música foram as velas que nos aconchegaram, nos uniram e nos alimentaram para seguir nossos caminhos, se não com a mesma força, mas pela mesma estrada: o da cidadania, o da alegria e compromisso com a coletividade, seja ela qual for e onde estiver.

João partiu de braços abertos e enfrentou a morte com mais força do que quando enfrentou um canhão e nos deixou mais um legado: não tenhamos medo da morte. Sorriu, com sua meninice, minutos após seus últimos suspiros. Sua despedida foi em tom de festa, assim como quando ele fez ao escrever o documentário Tributo a Chico Mendes (1988), após Chico ter sido assassinado. Havia um forró, todos dançavam, após a locução em off, com a conhecida voz de Reginaldo Cordeiro, que dava notícias da cida- de para os que moravam na floresta. Ele lia os bilhetes que familiares escreviam, desde os mais esdrúxulos, cômicos, trágicos, até os inverossímeis. Eu, levada pela força e pressão da academia, coloquei-o ao lado de Piscator, pois foi ele que, na história do espetáculo, inseriu a voz em off em seus documentários.

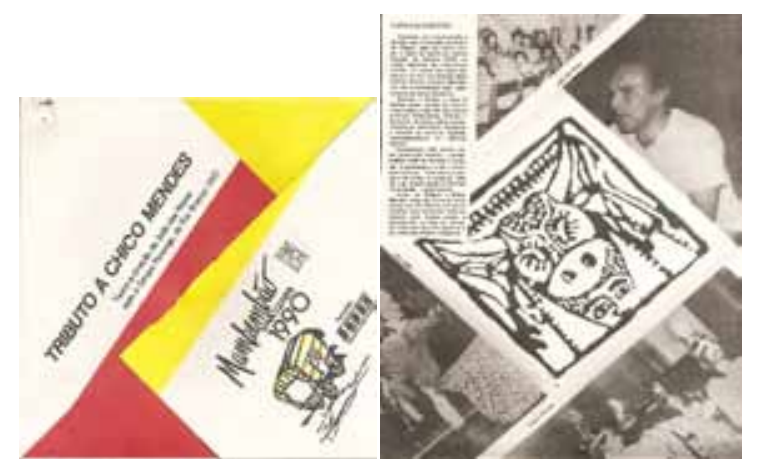

Fig. 2 e 3 - Segundo programa da peça Tributo a Chico Mendes. Acervo pessoal.

Passei boa parte de minha vida acadêmica lendo os autores elegidos como os clássicos e os importantes do momento na Academia. Piscator, Brecht e tantos outros importantes diretores teatrais, além de filósofos como Lucak, como para construir um alicerce de uma simples leitura de Yuraiá, o rio do nosso corpo (1992), precisava sustentar a obra do João nas dos outros, para que ela tivesse validade acadêmica. Fiz, a meia boca, mas fiz. São importantes, por suposto, mas há outros e nós, pesquisadores, precisamos nos livrar das amarras. 


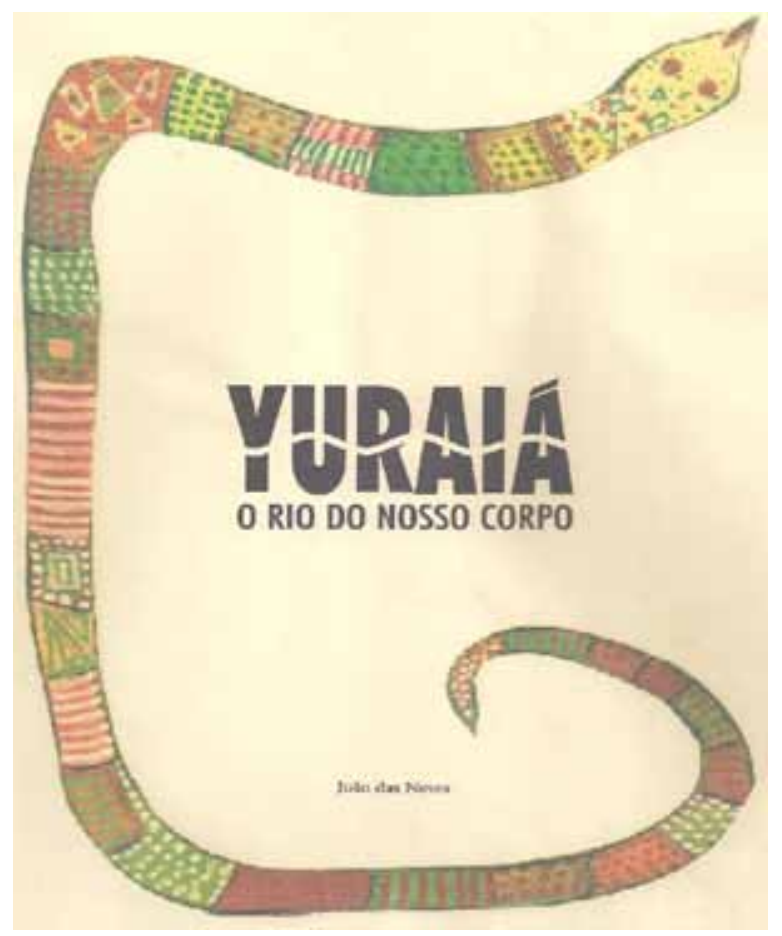

Fig. 4 - Capa original do texto Yuraiá,o rio do nosso corpo. Arquivo: João das Neves.

Eu permaneço

Nos anos luz de estrelas

Que não mais existem ${ }^{8}$

(João das Neves, 2014)

Somente no Curso de Artes Cênicas e com a experiência com assuntos inerentes à história do espetáculo, constatei que podia escrever e fazer relações que construí ao longo de minha docência, creio que decente. Por isso não me debruçarei sobre temas como teatro documentário, teatro épico, teatro de agit-prop, gestus, música gestus e até performance cultural. Ficarei com minhas histórias, com as histórias do João, pois ele foi, em persona, o próprio gestus. Acabo de chegar de Rio Branco (AC), e lá outra amiga - Clarisse Baptista $^{9}$ - me mostrou um certificado bonito de se ver: quando do evento da morte de 30 anos da morte de Chico Mendes, João das Neves foi inserido na lista dos trinta homens que ajudaram na consolidação das reservas extrativistas. Lá estava ele, ao lado de nomes de seringueiros assassinados e antropólogos.

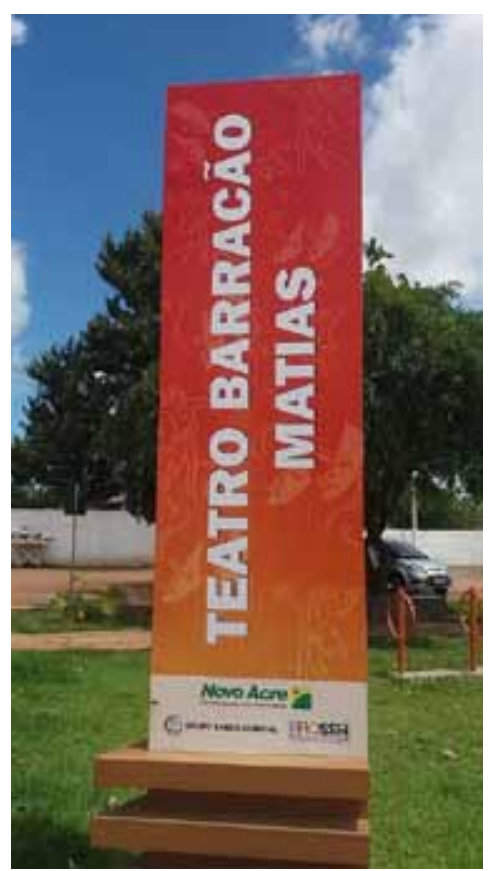

Fig. 5 - Foto recente da fachada do Teatro Barracão. Rio Branco -Acre. Um dos espaços onde João das Neves trabalhou. Acervo pessoal.

Um dia após saber sobre a homenagem a João, fui ao Teatro Barracão, espaço cultural recém-

\footnotetext{
${ }^{8}$ Poema não publicado. Acervo da autora.

${ }^{9}$ Clarisse Baptista trabalhou com João das Neves desde os 17 anos. Com atriz protagonista, com Lélia Abramo, na montagem de $A$ mãe, de Brecht, passou a realizar alguns trabalhos como assistente de direção $A$ missa do Quilombo e foi através dela que João das Neves foi para o Acre e, como ele, fundou o Grupo Poronga.
} 
-reformado pelo governo estadual. Ali, durante conversa com o atual administrador, Ney Ricardo, entreguei-lhe as cópias que tinha das peças de José Marques de Souza, conhecido como Matias. O material me fora disponibilizado para pesquisa pelo seu filho, Claudio Matias.

No livro $A$ cidade encena a floresta, há um capítulo inteiro dedicado à análise desse material. $\mathrm{Na}$ obra, também escrevo sobre João das Neves e seu Tributo a Chico Mendes. Para a encenação da peça, João contou com o ator amador Matias, homem vindo da floresta e um dos resistentes à política de ocupação do bairro onde fica o espaço Barracão. Ney Ricardo pediu para gravar minha fala e me fez algumas perguntas. Quis saber se Matias teria trabalhado com o teatro do oprimido, de Augusto Boal, e se nas peças dele havia traços da estética boalina.

Novamente, fiquei diante da catalogação de peças e, desta feita, de um homem - Matias - que mal conhecia o código linguístico escrito. Falei que Matias, assim como João das Neves, tivera contato com Augusto Boal, mas um - uma onça da floresta, conhecedor das pistas da mata e sensível ao espaço periférico que estava ocupando, e outro - famoso, letrado e intelectual, tinham construído sua própria forma de escrever. Destaquei que minha tarefa e cuidado como pesquisadora era justamente descobrir o gênero e a poética de cada um. Em algum momento escrevi sobre a presença de Boal no Acre e cheguei a publicar sobre o assunto em uma revista espanhola, mas nunca disse que João das Neves e Matias fizeram um teatro boalino.

$\mathrm{O}$ que quero dizer com essa comparação entre os dois diretores, constituídos a partir de espaços e experiências tão diferentes, é que o encontro foi de respeito e admiração mútuos e um alimentou o outro para a montagem de Tributo a Chico Mendes, na qual uma cena é dedicada à história de um caçador e uma onça. Eu diria que esta cena daria gosto para os leitores de Richard Schechner (2012), quando ele discute sobre comportamento restaurado.

Por fim, reitero meu objetivo neste texto sobre João das Neves: os artistas do teatro criam e recriam, e nós, como pesquisadores, temos a incumbência de conhecer as linguagens cênicas, o perfil dos espectadores, tanto de movimentos passados como dos atuais, para construir uma boa lupa de análise e não deixar a poética de cada um deles ser abafada por uma linguagem acadêmica e classificatória, 
colocando-os em um lugar onde a saia ou a calça ficam apertadas e formatadas, não deixando o artista permanecer, apenas passar.

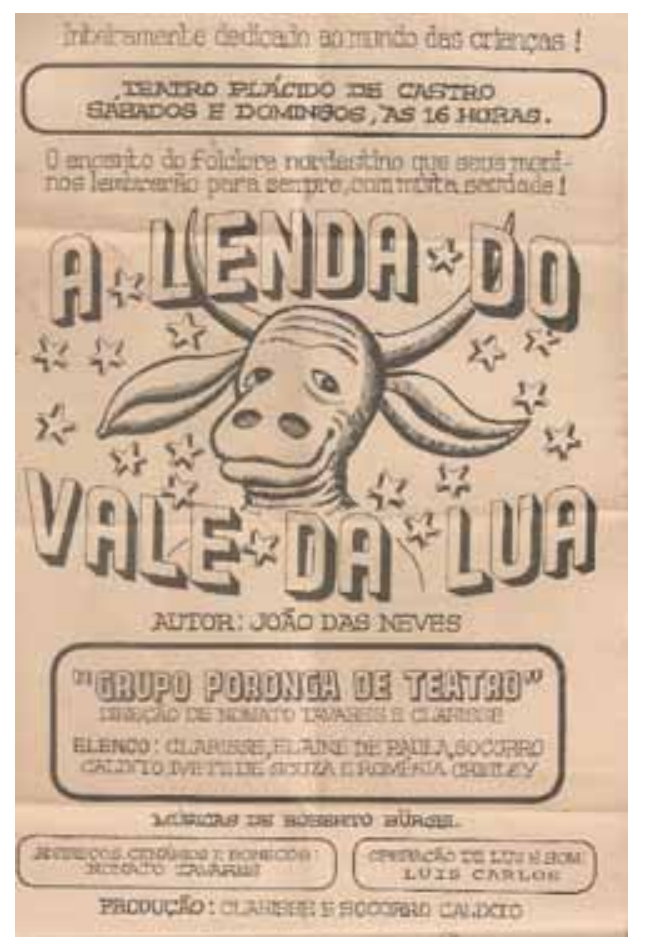

Fig. 6 - Cartaz da peça A Lenda do vale da lua. Grupo Poronga de Teatro. Local de Apresentação: Teatro Plácido de Castro Rio Branco Acre. Arquivo pessoal.

\section{A lenda do vale da Lua João das Neves}

João das Neves deixou um vasto material de peças voltadas para o público infanto-juvenil. Ao lado, um programa feito com papel jornal da peça A lenda do Vale da Lua, montada pelo Grupo Poronga, dirigida pelo amazonense Nonato Tavares e Clarisse Baptista. A peça lotou o teatro Plácido de Castro (Rio Branco-Acre) durante todos os dias de apresentação.

Produção: Clarisse e Socorro Calixto, ou esta que vos escreve.

Nunca escrevi sobre a Lenda do Vale da Lua ${ }^{10}$, pois minha lupa sempre foi o teatro, declaradamente político, como os documentários. Registro acima o cartaz porque minha memória foi lá longe buscar o João das Neves assistindo a nossos ensaios. No entanto, para reafirmar, mesmo quando escrevi sobre documentários e o teatro político de João das Neves, busquei sua poesia. Nesse sentido, apresento abaixo, um extrato de uma citação sobre Teatro Documentário, tipologia onde muitos colocaram o teatro de João das Neves:

O espectador do Teatro Documentário também pertence ao universo que está sendo exibido e performado. O Teatro Documentário está atrelado diretamente à produção da história oral. Isso é o que confere a atualidade para esse tipo de teatro. Justamente por isso é que ele ganha diferentes movimentos estéticos desde o seu surgimento no início do século XX até os dias de hoje. Porque a sociedade muda de acordo com o tempo, essas transformações fazem com que o teatro Documentário ganhe diferentes corpos e qualidades de encenação ao longo dos anos. [...] Nessa medida, o Teatro o Documentário será sempre um reflexo do seu tempo, lugar e das pessoas que o fazem. [...] Logo, o Teatro Documentário também se caracteriza por ser uma ação humana criativa em relação ao seu tempo, sendo uma inscrição por sua vez objetiva e subjetiva de leitura de alguém sobre o seu tempo. (GIORDANO, 2013, p. 12)

Ora, ao falar de melodrama, teatro dos jesuítas, teatro realista e de todos os ismos que se seguiram na história do espetáculo de teatro, posso me valer dessas

\footnotetext{
${ }^{10}$ Orientei um trabalho de conclusão de Curso sobre a peça. Ver: COELHO, Laíza. No Vale da Lua: nos versos de A História do Boizinho Estrela, de João das Neves. Relatório de pesquisa, Universidade Federal de Uberlândia. Uberlândia, 2011-2012.
} 
características para fundamentar minhas análises, pois são gerais e atendem o princípio primeiro da obra de arte: ela é social. Sendo social, nada mais natural que se relacione com ela, criando uma estética verossímil com o que o autor escolheu fazer, respeitando a construção de sentidos do espectador. É assim que vejo o trabalho de João das Neves: uma arte e vida compatíveis com o seu modo de ver e viver o mundo do teatro, de forma militante e poética. Tanto que, em seu velório, a festa, a prática do 'beber o morto', a cremação, cujas cinzas foram distribuídas pelos lugares que ele escolheu e amou: o rio Acre, o mar de Copacabana e o pé de pequizeiro, em Lagoa Santa, simbolizavam um outro espetáculo e não um funeral. João levou com ele um colar Kaxinauá, cujo desenho também está presente nos tecidos: há sempre um outro lado das coisas a ser observado. Relatando esse momento de despedida, trago uma das frases presente em seu texto publicado na Revista Palavra: "A leitura também deve ser pelo avesso; positivo e negativo são igualmente reveladores; o oposto pode ser meu igual $[\ldots .$.$] a morte não é$ senão a reafirmação da vida” (NEVES, 1999). Observando o direito e o avesso dos desenhos que estavam também em seu colar, ficamos com seu sorriso no seu doce silêncio.

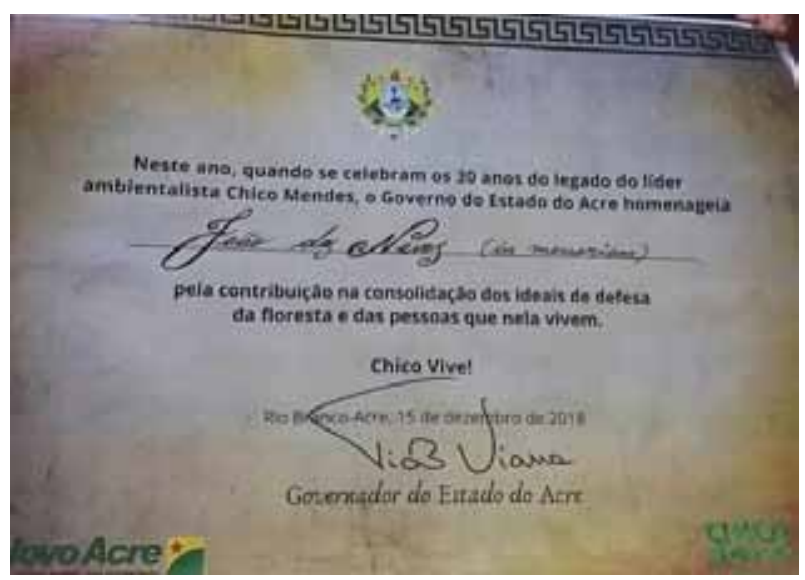

Fig. 7 - Foto do certificado que homenageia João das Neves (dezembro de 2018). Acervo oficial: Titane. 


\section{REFERÊNCIAS}

BAKHTIN, Mikhail. O conteúdo, a forma, o material. In: BAKHTIN, Mikhail. Estética da Criação Verbal. Trad. Maria Ermantina Galvão G. Pereira. São Paulo: Martins Fontes, 1997. p. 206-220.

BRECHT, Bertold. Estudos sobre teatro. Rio de Janeiro: Nova Fronteira, 2005.

CHARTIER, Roger. Práticas e representações: leituras camponesas em França no século XVIII. In: CHARTIER, Roger. A história cultural: entre práticas e representações. Rio de Janeiro: Editora Bertrand Brasil S.A, 1990. p. 141-163.

GIORDANO, Davi. Teatro Documentário Brasileiro e Argentino: o biodrama como a busca pela teatralidade do comum. Porto Alegre: arm@zém digital, 2014.

A cidade encena a floresta. Rio Branco: Edufac, 2005.

MARQUES, Maria do Perpétuo Socorro Calixto. Teatro de João das Neves: Opinião na Amazônia. 1. ed. Uberlândia: Edufu, 2016.

MARQUES, Lindalva Calixto. Entrevista cedida a Maria do Perpétuo Socorro Calixto Marques. Rio Branco-Acre, 1989.

NEVES, João das Neves. Um palco chamado floresta. Revista Palavra, Belo Horizonte, Ano 01, n. 05, p. 74-76, ago. 1999.

. Yuraiá, o rio de nosso corpo. Rio Branco-Acre, 1992. Não publicado.

. Aos que me amam. Lagoa Santa-MG, 2014. Não publicado.

. Caderno de Acontecimentos. Rio Branco-Acre, 1987. Não publicado.

. Tributo a Chico Mendes. Rio Branco-Acre, 1988. Não publicado.

A lenda do vale da lua. Montagem do Grupo Poronga. Rio Branco-Acre, 1989. Não publicado.

SCHECHNER, Richard. Restauração do comportamento. In: BARBA, Eugênio; SAVARESE, Nicola. A arte secreta do ator: um dicionário de antropologia teatral. Trad. Patrícia Furtado de Mendonça. São Paulo: É realizações Editora, Livraria e Distribuidora Ltda., 2012. p. 244-251. 
THOMASSEAU, Jean.-Marie. O Melodrama clássico (1800-1823). In: THOMASSEAU, Jean.-Marie. O Melodrama. Trad. Claudia Braga e Jacqueline Penjon. São Paulo: Perspectiva, 2005, p. 27-62.

TOCANTINS, Leandro. O rio comanda a vida: uma interpretação da Amazônia. Rio de Janeiro: Record, 1988 


\begin{abstract}
This text results more from a feeling that arose after João das Neve's death than from an academic analysis of his work. A feeling that triggers an emotive memory concerning the experience of having worked with him and been among the people that integrated the group that stayed in his house, in Lagoa Santa (MG/BR), during the days that preceded his passing. This memory made me look for some reading and experience contexts from Acre, some of which have inspired João das Neve's texts as, for instance, Yuraiá - the river of our body (1992).
\end{abstract}

\title{
Keywords
}

Theatre. Memory. Passion. Death. Experience. 